\title{
Analysis of vibration and noise of an internal combustion engine by application of test and experimental analysis of the frequency spectrum
}

\author{
Claudio Marcio Santana ${ }^{1}$, Jose Eduardo Mautone Barros ${ }^{2}$ e Helder Alves de Almeida Junior ${ }^{3}$ \\ Universidade Federal de Minas Gerais ${ }^{1.2}$ \\ Centro Federal de Educação Tecnológica ${ }^{3}$
}

$\underline{\text { claudiowsantana@gmail.com, mautone@demec.ufmg.br, helder.alves.eng@gmail.com }}$

\begin{abstract}
The problems of vibration and noise from an internal combustion engine are common because of the wide variety of parts and components that make up an internal combustion engine. In recent years engines have evolved considerably in relation to the control of vibration and noise emitted, since these effects reduce the useful life of the internal components of the engine itself and, besides giving discomfort to the occupants of the vehicle. The objective of this work was to identify and describe the main sources of vibration and noise in an internal combustion engine. The methodology used in this work involved instrumentation of an internal combustion engine (Otto cycle), the experimental tests of the engine on a test bench and involved the application of analytical techniques for treatment and analysis of experimental data.
\end{abstract}

\section{INTRODUCTION}

In the analysis of vibration and noise in an internal combustion engine, see that the major sources of noise and vibration forces are produced due to combustion and mechanical forces. These forces occur over a wide frequency range and are passed to the external surface of the engine. As a result of the action of these forces, the external surfaces of the engine are subject to vibrations of different amplitudes. This study aimed to determine and meet the main sources of vibration exciter in an 
internal combustion engine, through experimental measurement and application of an analytical method, which involves comparing the modes of vibration of the components involved in the trial.

\section{LITERATURE REVIEW}

The internal combustion engines are designed to transform the chemical energy contained in fuel into mechanical energy by burning the fuel air mixture theoretical. [1]

For its operation, the engine needs a source of energy: the fuel. Fuels may be liquid or gaseous. The most commonly used fuels are gasoline, ethanol and diesel. Natural gas has been recently employed as an alternative energy source [2].

The actual cycle spark ignition engines differ much from the ideal cycle on several factors. The efficiency of the actual cycle is much smaller than the ideal cycle due to various losses that occur in an actual engine operation [3]. The biggest losses are:

Variation of specific heat with temperature;

Dissociation products of combustion;

Progressive combustion;

Incomplete combustion;

Heat transfer walls of the combustion chamber;

Blow-down at the beginning of the process of exhaustion;

Process of gas exchange;

\subsection{Operating principle of spark ignition engines}

First time - Admission: When the piston descends from the TDC to BDC, in this moment the intake valve is open and the exhaust valve is closed, it creates a depression inside the cylinder, thus a certain amount of air is sucked into the cylinder. As air enters the intake valve a quantity of fuel injected is required by carburetor or injector to generate the air / fuel mixture to be burnt inside the cylinder, [4] and [5]. 
Second time - Compression: Once the piston reaches the BDC starts the compression with the inlet valve has opened. It will close a few degrees after the BDC to take the inertia of gases increasing cylinder filling. Shortly after the piston returns to the TDC with all the valves closed and compressing the mixture. This increases the pressure and temperature within the cylinder, near the end of compression is provided by a spark of the spark plug and the combustion is initiated [4] and [5].

Third time - Combustion and Expansion: The combustion starts before TDC and ends at the beginning of the expansion. The combustion raises the temperature and pressure for the maximum values of the cycle by changing the composition of the air / fuel mixture to the combustion products. With closed valves, the high pressure generated by the combustion pushes down the piston produces work cycle of the engine and decreasing the pressure and temperature within the cylinder [4] and [5].

Blow down: Is the opening of the discharge valve during the expansion of the gases. The pressure inside the cylinder is still high and the difference between the cylinder pressure and the atmospheric pressure causes the gases of combustion are expelled and the pressure in the cylinder decreases sharply. These gases still have a lot of enthalpy, which reduces the efficiency of the thermal cycle [4] and [5].

Fourth time - Discharge: When the piston reaches the BDC there is still a quantity of gas in the cylinder to approximately atmospheric pressure. As the exhaust valve remains open cylinder expels these remaining combustion gases during their journey from BDC to TDC, leaving only the volume of the combustion chamber occupied by these gases. At the end of the time to exhaustion, the intake valve begins to open and the exhaust valve to close. This time both valves are open simultaneously is called crossover valves. This helps in the exchange of the remaining gas combustion by mixing fresh coming from the intake valve. At the end of the exhaust cycle restarts [4] and [5].

\subsection{Vibrations in the automotive area}

The self-propelled vehicle is an extremely complex system, when it comes to sources of vibration and noise. This is because the vibration and noise emitted by vehicle is the result of contributions from many sources that act simultaneously transmitted from its origins. These characteristics make it difficult, in most cases, an individual analysis of sources in relation to 
legislative matters, in order to know the contribution of each to the overall external result [6] and [7].

\subsection{Noise and vibration from the engine}

The engine due to their constructive and functional characteristics is without any doubt the major source of noise and vibration of the vehicle, because the engine is through the vibrations and noises are transmitted to the body and thus felt by the occupants of the automobile. The total vibration from the engine can be divided basically into two major groups [6].

\subsection{Vibrations due to the combustion process}

The vibration is generated due to the reaction of the air blast fuel under high temperature and high pressure in the combustion chamber caused by the addition of heat in each of the cylinders. The type of fuel used has a direct influence by establishing special characteristics for this type of vibration. Normally in diesel engines, due to its high compression ratio, the vibrations are more intense compared to the OTTO cycle engines [6].

\subsection{Vibrations due to mechanical forces}

It is considered less influence over the vibrations generated by the explosion of gases, the most important contributions are the pistons and valves. The vibrations from the pistons are caused by the impact of the same on the cylinder walls, due lateral movement or tilted. Already the vibrations generated by the valves may be caused by metallic contact areas between the instant of valve seals and valve seats during the opening and closing of valves, driven by impulsive forces generated by the geometry of the eccentric camshaft valves [6].

\subsection{Structure of the engine}

These forces occur over a wide frequency range and are passed to the outer surface of the engine through several pathways, one of them is through the engine piston - piston rod - crank - the engine block. As a result of the action of these forces, the external surfaces of the engine are subject to vibrations of different amplitudes [6] and [7]. 


\section{METHODOLOGY}

The methodology involves the experimental procedure for the testing of internal combustion engines, such procedures involve equipment used, engine instrumentation, data acquisition equipment and procedures for calculations and processing of experimental data.

In the test used a hydraulic hand dynamometer, which is a device for measuring the absorption and power produced by a source able to trigger it in the event the internal combustion engine.

The Spark instrumented was used to measure the combustion pressure of the engine. The pressure inside the cylinder is measured by a sensor installed in the spark plug, which is able to withstand high temperatures and pressures within the cylinder.

In the test were used pressure sensors adapted together with the inlet and outlet collectors for the purpose of recording pressure data within these conduits.

\subsection{Experimental Procedures}

In this work used an engine flex fuel 8 valves $1400 \mathrm{cc}$. This assay was performed in rotation 1500 RPM at part load (16\% of the opening of the throttle), 2250 RPM with full and partial load, 3875 RPM with full and partial load and full load $5500 \mathrm{rpm}$. We used the $15 \mathrm{~W} 40$ lubricating oil and fuel gasoline. It was used as a condition for data acquisition average water temperature around $95^{\circ} \mathrm{C}$ and oil at $135^{\circ} \mathrm{C}$. The test consisted of running the engine in specific rotation and after stabilization of the temperature of the water and oil data (referring to measured pressure sensors and sailing instrumented) were measure and stored in the Software "Indicom" of the AVL.

\subsection{Analysis of the experimental data}

Measured data concerning rotations 1500 RPM at part load, 2250 RPM with partial and full load, part load 3875 RPM and 5500 RPM with full and total charge were previously measured and stored in the Software Indicom. 
The software MATLAB was used to plot for each rotation of the graphs above-mentioned combustion pressure in the cylinder, the intake manifold pressure, exhaust manifold pressure and engine speed as a function all the time. For best viewing results became the graphics that were in the time domain to the frequency domain. Subsequently for each rotation and load type (partial or total) were grouped in the same graph parameters combustion pressure in the cylinder pressure in the intake manifold pressure in the discharge manifold and engine speed. It was not possible to examine these graphs perfect because of the large pressure difference between the cylinder (combustion pressure) and intake manifolds and exhaust. Then decided to divide the values of the amplitudes of cylinder pressure, pressure in the intake manifold and exhaust manifold for specific values in order to make the parameters in the same order of magnitude and thus facilitate the visualization of the results. We emphasize that this does not affect the results, since what is important in the analysis are the peaks of dominant frequencies and not the amplitudes. Tables 1-6 show the amplitudes derived from the Fourier transform, the correction factor by which the original amplitude was divided and amplitude corrected.

Table 1 - Ranges originated Fourier transform, amplitude correction factor and corrected of 1500 RPM of partial load.

\begin{tabular}{|c|c|c|c|}
\hline \multicolumn{4}{|c|}{1500 partial load } \\
\hline Parameter & $\begin{array}{c}\text { Amplitude } \\
\text { original }\end{array}$ & $\begin{array}{c}\text { Factor of } \\
\text { correction }\end{array}$ & $\begin{array}{c}\text { Amplitude } \\
\text { correction }\end{array}$ \\
\hline Cylinder & 492300 & 246150 & 2 \\
\hline Admission & 1362 & 972,85 & 1,4 \\
\hline Exhaust & 3439 & 1910,55 & 1,8 \\
\hline Rotation & 29,52 & 29,52 & 1 \\
\hline
\end{tabular}

Table 2 - Ranges originated Fourier transform, amplitude correction factor and corrected of 2500 RPM of partial load.

\begin{tabular}{|c|c|c|c|}
\hline \multicolumn{4}{|c|}{2500 partial load } \\
\hline Parameter & $\begin{array}{c}\text { Amplitude } \\
\text { original }\end{array}$ & $\begin{array}{c}\text { Factor of } \\
\text { correction }\end{array}$ & $\begin{array}{c}\text { Amplitude } \\
\text { correction }\end{array}$ \\
\hline Cylinder & 399500 & 199750 & 2 \\
\hline Admission & 1236 & 882,85 & 1,4 \\
\hline Exhaust & 4506 & 2503,33 & 1,8 \\
\hline Rotation & 7,70 & 7,70 & 1 \\
\hline
\end{tabular}


Table 3 - Ranges originated Fourier transform, amplitude correction factor and corrected of 2500 RPM of full load.

\begin{tabular}{|c|c|c|c|}
\hline \multicolumn{5}{|c|}{2500 full load } \\
\hline Parameter & $\begin{array}{c}\text { Amplitude } \\
\text { original }\end{array}$ & $\begin{array}{c}\text { Factor of } \\
\text { correction }\end{array}$ & $\begin{array}{c}\text { Amplitude } \\
\text { correction }\end{array}$ \\
\hline Cylinder & 697300 & 348650 & 2 \\
\hline Admission & 2951 & 2107,85 & 1,4 \\
\hline Exhaust & 8257 & 4587,22 & 1,8 \\
\hline Rotation & 21,05 & 21,05 & 1 \\
\hline
\end{tabular}

Table 4 - Ranges originated Fourier transform, amplitude correction factor and corrected of 3875RPM of partial load.

\begin{tabular}{|c|c|c|c|}
\hline \multicolumn{5}{|c|}{3875 partial load } \\
\hline Parameter & $\begin{array}{c}\text { Amplitude } \\
\text { original }\end{array}$ & $\begin{array}{c}\text { Factor of } \\
\text { correction }\end{array}$ & $\begin{array}{c}\text { Amplitude } \\
\text { correction }\end{array}$ \\
\hline Cylinder & 269200 & 134600 & 2 \\
\hline Admission & 2292 & 1637,14 & 1,4 \\
\hline Exhaust & 2591 & 1439,44 & 1,8 \\
\hline Rotation & 11,66 & 11,66 & 1 \\
\hline
\end{tabular}

Table 5 - Ranges originated Fourier transform, amplitude correction factor and corrected of 3875 RPM of full load.

\begin{tabular}{|c|c|c|c|}
\hline \multicolumn{5}{|c|}{3875 full load } \\
\hline Parameter & $\begin{array}{c}\text { Amplitude } \\
\text { original }\end{array}$ & $\begin{array}{c}\text { Factor of } \\
\text { correction }\end{array}$ & $\begin{array}{c}\text { Amplitude } \\
\text { correction }\end{array}$ \\
\hline Cylinder & 769500 & 384750 & 2 \\
\hline Admission & 5010 & 2783,33 & 1,4 \\
\hline Exhaust & 4856 & 3468,57 & 1,8 \\
\hline Rotation & 27,67 & 27,67 & 1 \\
\hline
\end{tabular}


Table 6 - Ranges originated Fourier transform, amplitude correction factor and corrected of 5500 RPM of full load.

\begin{tabular}{|c|c|c|c|}
\hline \multicolumn{5}{|c|}{5500 full load } \\
\hline Parameter & $\begin{array}{c}\text { Amplitude } \\
\text { original }\end{array}$ & $\begin{array}{c}\text { Factor of } \\
\text { correction }\end{array}$ & $\begin{array}{c}\text { Amplitude } \\
\text { correction }\end{array}$ \\
\hline Cylinder & 686400 & 343200 & 2 \\
\hline Admission & 11150 & 6194,44 & 1,4 \\
\hline Exhaust & 9468 & 6762,85 & 1,8 \\
\hline Rotation & 21,56 & 21,56 & 1 \\
\hline
\end{tabular}

Stipulated that the dominant frequencies for each rotation, this was done by dividing the rated speed measured in RPM by 60, which results in values in Hz. The Table 7 shows the speed test, the dominant frequencies and their multiples also known as harmonics.

Table 7 - Rotation test and dominant frequency and its harmonics up to the fifth order.

\begin{tabular}{|c|c|c|c|c|c|}
\hline Rotation & $1 / \mathrm{N}$ & $\mathrm{N}$ & $2 \mathrm{~N}$ & $3 \mathrm{~N}$ & $4 \mathrm{~N}$ \\
\hline 1500 & 12,50 & 25,00 & 50,00 & 75,00 & 100,00 \\
\hline 2250 & 18,75 & 37,50 & 75,00 & 112,50 & 150,00 \\
\hline 3875 & 32,29 & 64,58 & 129,16 & 198,74 & 258,32 \\
\hline 5500 & 45,83 & 91,67 & 183,34 & 275,01 & 366,68 \\
\hline
\end{tabular}

In order to relate possible sources of vibration excitation amplitudes with some frequency, we calculated the frequencies of resonance intake manifold, and exhaust plenum. Equations 1 and 2 proposed by Kinsler, 1980 are used to calculate these frequencies.

$$
\text { Freq. }=C x \sqrt{\frac{s}{L x V o}}
$$

Where:

$\mathrm{C}=$ propagation speed of sound in air.

$\mathrm{S}=$ cross-sectional area.

$\mathrm{L}=$ length of the tube.

Vo $=$ volume of the plenum 


$$
\text { Freq. }=C x \frac{N}{2 X L}
$$

Where:

$\mathrm{C}=$ propagation speed of sound in air.

$\mathrm{N}=$ Number of harmonics.

$\mathrm{L}=$ length of the tube.

\section{RESULTS AND DISCUSSION}

The figures 2-7 show the graphs of pressure in the cylinder pressure in the intake manifold, exhaust manifold pressure and engine speed. The tests was conducted at $1500 \mathrm{rpm}$ at partial load, $2250 \mathrm{rpm}$ with partial and full load, part load $3875 \mathrm{rpm}$ and $5500 \mathrm{rpm}$ with full and total charge. To better visualize the graphs are presented in the frequency domain.

In general it is observed that the curves of combustion pressures have amplitudes of frequencies at half rotation, the rest of the spectrum curves show a continuous and uniform behavior until about $400 \mathrm{~Hz}$ pressure combustion is responsible for the appearance of the peak frequency rotation curves.

In general it is observed that the curves of revolutions are well defined ranges of frequencies $2,4,6$, $8 \mathrm{X}$ and the dominant frequency. These frequencies are influenced by combustion pressure in the cylinder. This is explained by the fact of having four combustion (one per cylinder) in $720^{\circ}$ rotation of the crankshaft, which is equivalent to twice around the shaft. So considering 360 has two combustion occurring which brings up these amplitudes in multiples of 2 from the dominant frequency.

In this same curve is visible frequency range near $300 \mathrm{~Hz}$ in all rotations. It is estimated that this excitation is related to an event linked to the crankshaft can be: the first flexural vibration mode, first torsion vibration mode or the natural frequency of the shaft. This issue will be discussed later.

In the curves for the collectors will see a range of frequency that amplitudes are not influenced neither the combustion pressure or engine speed, namely $137-240 \mathrm{~Hz}$ at admission and 450-680 Hz 
in the discharge will be further adopted a methodology relate to the possible excitation sources of these frequency.

FFTsa 1500 rom em carga parcial

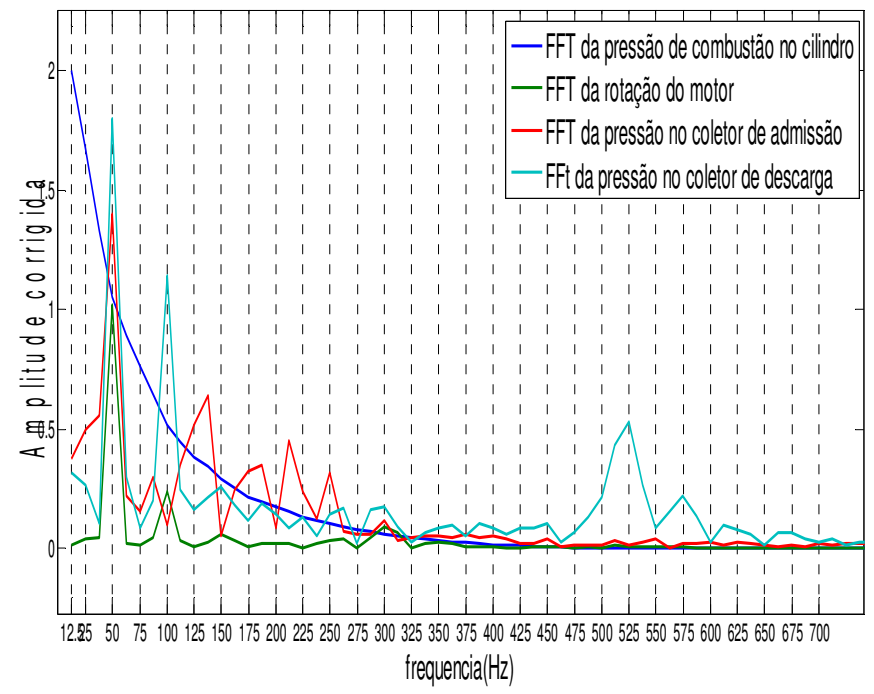

Figure 2 - Graph of cylinder pressure, intake manifold, exhaust manifold and engine speed of 1500 RPM to partial load.

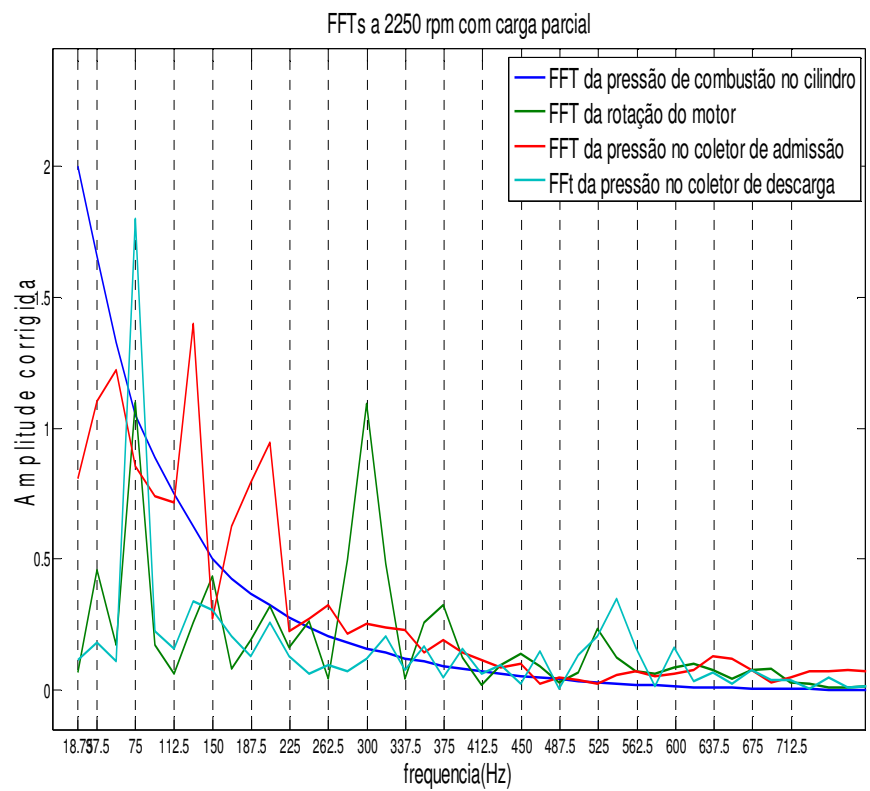

Figure 3 - Graph of cylinder pressure, intake manifold, exhaust manifold and engine speed of 2250 RPM to partial load. 


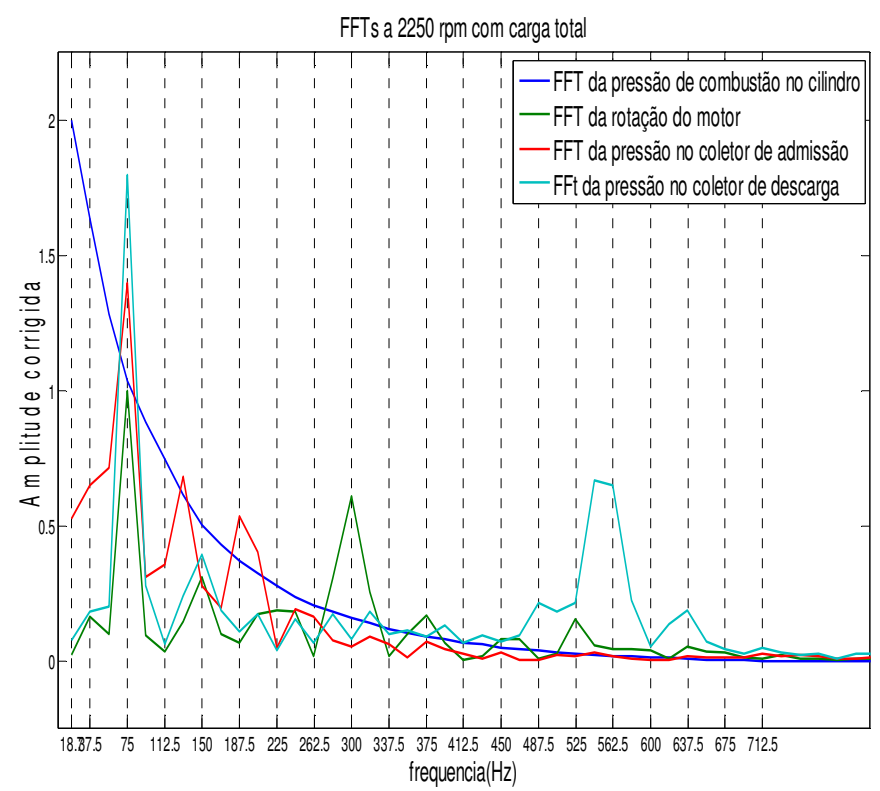

Figure 4 - Graph of cylinder pressure, intake manifold, exhaust manifold and engine speed of 2250 RPM to full load.

FFTs a 3875 rom com carga parcial

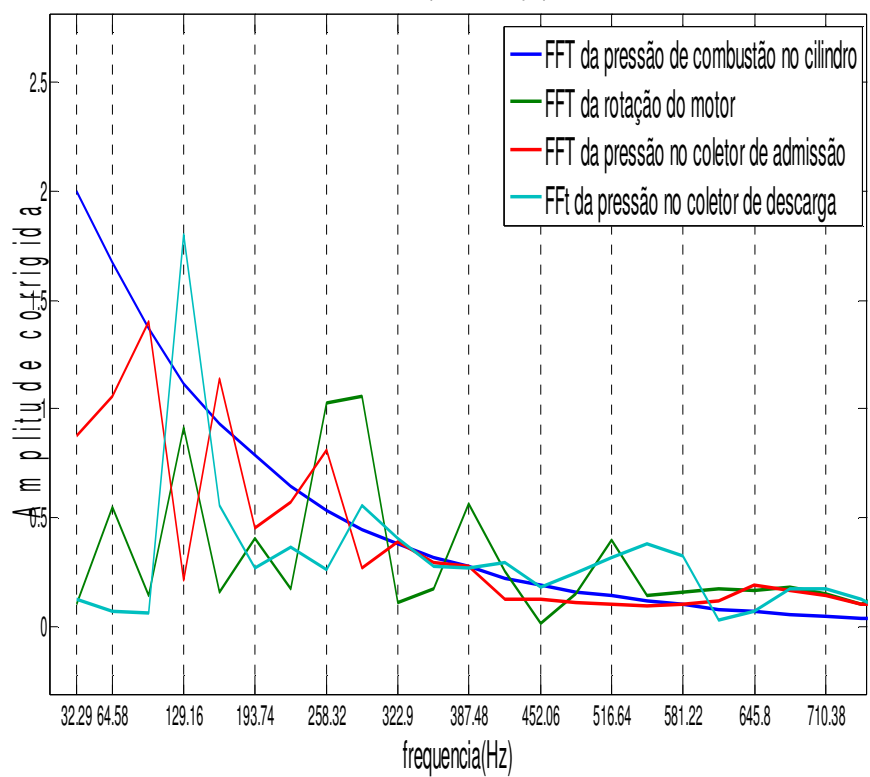

Figure 5 - Graph of cylinder pressure, intake manifold, exhaust manifold and engine speed of 3875 RPM to partial load. 


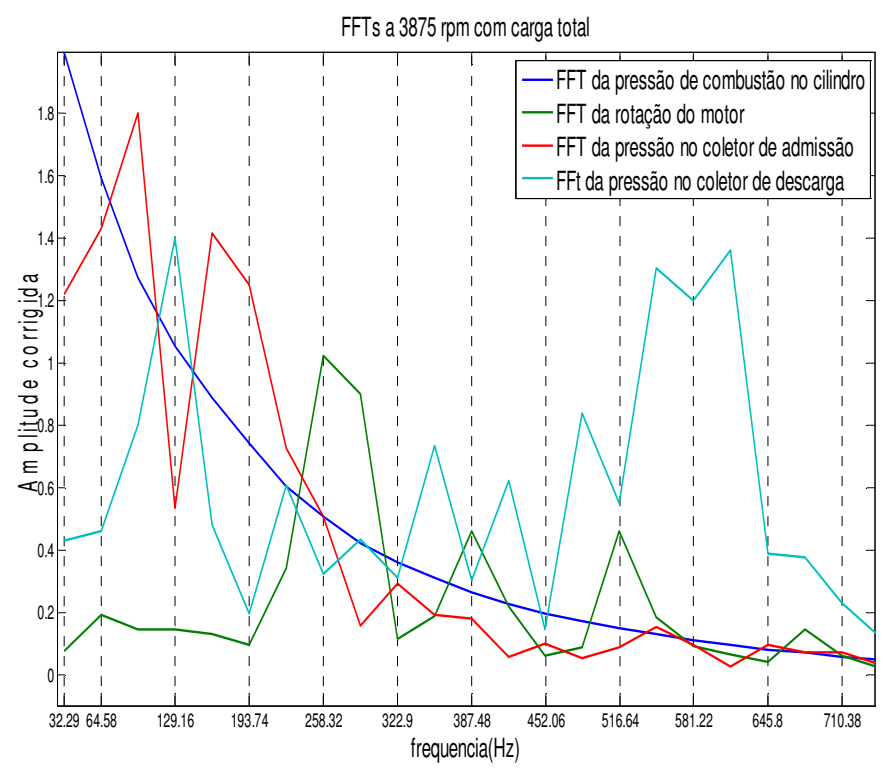

Figure 6 - Graph of cylinder pressure, intake manifold, exhaust manifold and engine speed of 3875 RPM to full load.

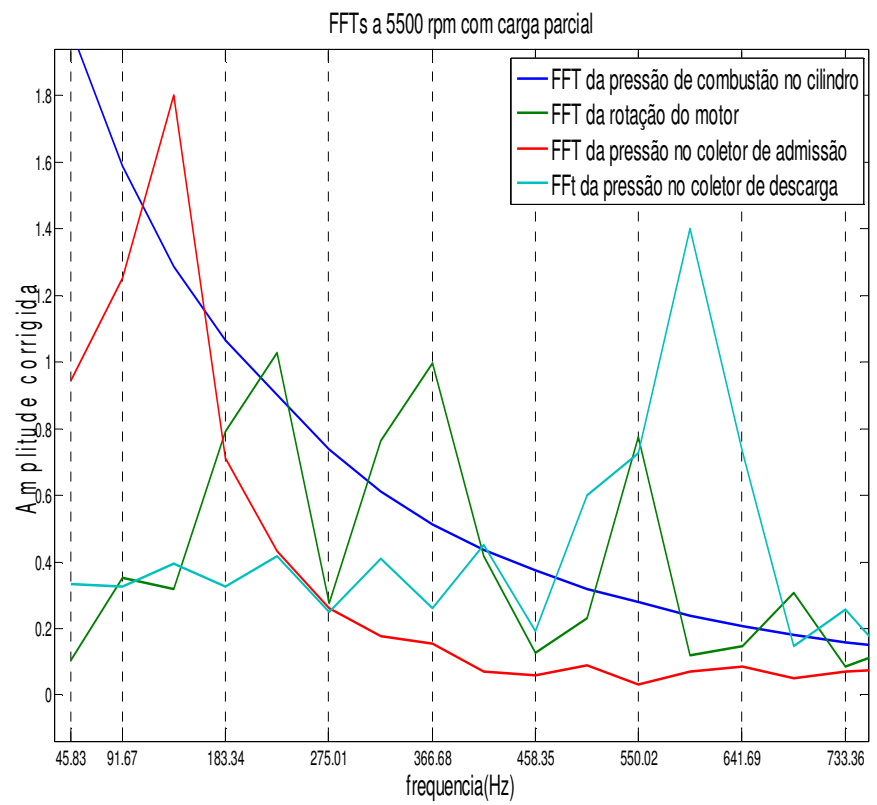

Figure 7 - Graph of cylinder pressure, intake manifold, exhaust manifold and engine speed of 5500 RPM to partial load.

Tables 7 and 8 show respectively the calculation of the resonance frequencies of intake manifolds and discharge taking into account the lengths of the central tubes, side pipes collectors, plenum volume of the intake manifold and the muffler volume in the discharge manifold. The calculations have to evaluate if any of the resonance frequencies is acting as the excitation source, since there is the presence of prominent frequencies of vibration and almost constant at all speeds in both curve on admission and discharge curve. The methodology used for calculating the equations 1 and 2 shown

earlier. 
In the curve entrance these frequencies appear in a band ranging from 137 to $250 \mathrm{~Hz}$ in the calculations as shown in the table below, values are doubled. It is concluded that the intake manifold is a source exciter, whose frequencies of excitations are roughly half the resonance frequency.

Table 7 - Calculation of resonant frequencies in the intake manifold.

\begin{tabular}{|c|c|}
\hline \multicolumn{2}{|c|}{ Frequency of resonance in the intake manifold } \\
\hline Condition & (HZ) \\
\hline Plenum and side length of the tube collector & 467,27 \\
\hline Plenum and center length of the tube collector & 468,25 \\
\hline Side length of the tube collector & 447,93 \\
\hline center length of the tube collector & 449,83 \\
\hline $\begin{array}{r}\text { Plenum and center length of the valve throttle at } \\
\text { entry of plenum }\end{array}$ & 992,27 \\
\hline
\end{tabular}

In the discharge curve which appear in the frequency range 450-680 Hz The table below shows the values calculated in the same order of magnitude considering the first two situations. It is concluded that the discharge manifold is also a source exciter, whose frequencies of excitations are more or less equal to the resonance frequency.

Table 8 - Calculation of resonant frequencies in the discharge manifold.

\begin{tabular}{|c|c|}
\hline \multicolumn{2}{|c|}{ Frequency of resonance in the discharge manifold } \\
\hline Condition & $(\mathrm{HZ})$ \\
\hline Close cup and side length of the tube collector & 417,79 \\
\hline $\begin{array}{c}\text { Close cup and center length of the tube } \\
\text { collector }\end{array}$ & 757,63 \\
\hline Side length of the tube collector & 1064,56 \\
\hline center length of the tube collector & 3500,83 \\
\hline
\end{tabular}

Table 9 shows the simulation results of crankshaft made in ANSYS software, the purpose of the calculations is to relate somehow vibration frequency of $300 \mathrm{~Hz}$ found in the rotation curves. It appears from the table below that the first mode of crankshaft torsion vibration is $278.4 \mathrm{~Hz}$, then the frequency of $300 \mathrm{~Hz}$ which appears in the curves during the rotation test is being excited by the first mode of torsion vibration of the shaft crankshaft. 
Table 9 - Modes of vibration of the crankshaft

\begin{tabular}{|l|l|}
\hline \multicolumn{1}{|c|}{ modes of vibration of the crankshaft } & $(\mathrm{HZ})$ \\
\hline First mode of vibration flexion vertical & 134,21 \\
\hline First mode of vibration flexion horizontal & 190,61 \\
\hline First mode of vibration torsion & 278,4 \\
\hline
\end{tabular}

\section{CONCLUSIONS}

The application of the test and experimental analysis of frequency spectrum has pinpointed accurately from the vibrations of the combustion process, noise from the valve train system (opening closing of the intake valves and exhaust) and noise from the flow of the air / fuel in the intake manifold and combustion gases in the discharge manifold.

\section{REFERENCES}

[1] HEYWOOD, John B. Internal Combustion Engine Fundamentals. 1.ed. New York: McGraw-Hill, Inc., 1988.

[2] BOSCH, R. Manual de Tecnologia Automotiva. 25.ed. São Paulo: Edgard Blücher, 2005.

[3] GANESAN, V. Internal Combustion Engines. 1.ed. New York: McGraw-Hill, Inc., 1995.

[4] BAÊTA, J. G. Metodologia Experimental para a Maximização do Desempenho de um Motor Multicombustível Turbo alimentado sem Prejuízo à Eficiência Energética Global. Belo Horizonte: Tese de Doutorado, Engenharia Mecânica, UFMG, 2006.

[5] BARROS, J. E. M. Estudo de Motores de Combustão Interna Aplicando Análise Orientada a Objetos, Belo Horizonte: Engenharia Mecânica, UFMG, 2003.

[6] GERGES, SAMIR NAGI YOUSRI Ruídos e Vibrações Veiculares. $1^{\circ}$ edição -Florianópolis 2005. 
[7] SILVA,C,W Vibration: Fundamentals and Practice, Boca Raton: CRC Press LLC, 2000 